МАРКИН Валерий Васильевич - доктор социологических наук, профессор, главный научный сотрудник Института социологии Федерального научно-исследовательского социологического центра РАН (117218, Россия, г. Москва, ул. Кржижановского, 24/35, корп. 5; markin@isras.ru)

ВОРОНОВ Виктор Васильевич - доктор социологических наук, профессор, ведущий научный сотрудник Института социологии Федерального научно-исследовательского социологического центра РАН (117218, Россия, г. Москва, ул. Кржижановского, 24/35, корп. 5; voronov@isras.ru)

\title{
МАЛЫЕ ГОРОДА РОССИИ: ЭКСПЕРТНОЕ ИЗМЕРЕНИЕ ГОСУДАРСТВЕННОЙ ПОЛИТИКИ
}

\begin{abstract}
Аннотация. В статье, основанной на результатах полевого социологического исследования, проведенного Центром региональной социологии ФНИСЦ РАН в июле-августе 2019 г. в 8 федеральных округах РФ, представлены оценки экспертов о роли и факторах жизнедеятельности малых городов в российских регионах. Оценки сделаны в аспекте государственной политики пространственного развития страны. Авторы аргументируют возможности и барьеры для реализации такой политики в интересах большинства жителей малых городов. В выводах показаны ограниченность узкоэкономического подхода к будущему малых городов, необходимость увеличения их роли в производстве и воспроизводстве общероссийских ценностей, укреплении суверенной национальной безопасности и стабильности страны.

Ключевые слова: малые города, регионы, государственная политика, оценки экспертов, развитие, возможности и барьеры
\end{abstract}

Введение. В современной России из 1114 городов 792 являются малыми (с численностью населения до 50 тыс. чел.). В них проживают свыше 16 млн чел., или около $12 \%$ населения страны. Геополитические и социально-экономические трансформации России после 1991 г. образовали комплекс проблем для развития малых городов: закрытие или сокращение градообразующих предприятий, узкая специализация рынка труда без прямой возможности перепрофилирования, обветшание городской инфраструктуры, снижение уровня и качества жизни, социально-трудовая маргинализация населения (особенно молодежи), отток населения и многое другое. Это оказывает возрастающее влияние на повышение конфликтогенности, на риск нарушения государственной устойчивости и безопасности пространственного развития страны. Мировой опыт показывает, что есть разные пути решения проблемы малых городов: американский - жители переезжают в другие места, где есть работа; в результате город сжимается в размерах, но при этом сохраняет свои городские функции. Европейский путь предполагает государственные и региональные программы санации территории, направленные на снижение зависимости таких городов от градообразующих предприятий, кооперацию хозяйственной деятельности аналогичных городов на кластерных принципах, улучшение качества городской среды. В рамках российских инициатив по решению проблем малых городов также предлагаются различные модели их решения и развития. Например, модель «управляемое сжатие) - для городов с закрывающимся градообразующим предприятием и без достаточного потенциала развития городской экономики; модель «стабильный моногород» - для поселений со стабильно работающим градообразующим предприятием, но без значительного потенциала развития альтернативной экономики; модель «индустриальная диверсификация» - для городов со значительным инвестиционным потенциалом и др. [Землянский, Ламанов 2014; Малые города... 2014].

Для выявления возможностей и барьеров в социальных и политико-управленческих практиках, применяемых в отношении малых городов, было проведено социологическое исследование в 16 типичных российских городах с чис- 
ленностью до 50 тыс. жителей, отобранных с учетом российских структурнопространственных факторов и условий. В 8 российских федеральных округах (ФО) взяты типичные для них регионы (край или область), где отобраны по 2 малых города: входящий в агломерацию крупного города (25-30 км от крупного города или в пределах часовой транспортной доступности) и не входящий в агломерацию пространственно локализованный город. Исходя из этих принципов были отобраны следующие 16 малых городов (в т.ч. 6 моногородов) в 8 краях и областях:

Центральный $Ф О$ - Тверская обл.: г. Лихославль в агломерации г. Твери (11,8 тыс. чел.); г. Кимры - вне агломерации (46 тыс. чел.).

Северо-Западный $Ф О$ - Вологодская обл.: г. Сокол в агломерации г. Вологды (37 тыс. чел.); г. Красавино - вне агломерации (6 тыс. чел.).

Южный ФО - Ростовская обл.: г. Аксай в агломерации г. Ростова-на-Дону (44,8 тыс. чел.); г. Миллерово - вне агломерации (35,5 тыс. чел.).

Северо-Кавказский ФО - Ставропольский край: г. Изобильный в агломерации г. Ставрополя (40,5 тыс. чел.); г. Новоалександровск - вне агломерации (26,9 тыс. чел.).

Приволжский ФО - Нижегородская обл.: г. Балахна в агломерации г. Нижнего Новгорода (14,9 тыс. чел.); г. Заволжье - вне агломерации (14,9 тыс. чел.).

Уральский $Ф О$ - Свердловская обл.: г. Среднеуральск в агломерации г. Екатеринбурга (23,3 тыс. чел.); г. Ирбит - вне агломерации (37,2 тыс. чел.).

Сибирский $Ф O$ - Иркутская обл.: г. Шелехов в агломерации г. Иркутска (47,6 тыс. чел.); г. Зима - вне агломерации (31,2 тыс. чел.).

Дальневосточный $О$ - Приморский край: г. Большой Камень в агломерации г. Владивостока (38 тыс. чел.); г. Спасск-Дальний - вне агломерации (40,7 тыс. чел.).

Методология и методы исследования. Материал основан на опросе экспертов - компетентных специалистов в каждом из обследуемых городов: представителей исполнительных и законодательных органов власти, малого и среднего бизнеса, представителей общественных организаций (гражданского общества), СМИ. В июле-августе 2019 г. были проведены структурированные глубинные интервью, включающие балльные оценки тех или иных факторов развития (актуальное состояние, перспективы и ограничения) по анкете и качественные характеристики этих факторов в указанных городах с 80 экспертами (по 5 в каждом из 16 обследуемых малых городов). Количественные данные были обработаны в программе SPSS, качественные характеристики транскрибированы из аудиозаписей интервью. Отбор экспертов осуществлялся с целью представленности органов власти, активных акторов в малых городах и распределения их компетенций. Постановка открытых и закрытых вопросов на основе специально разработанной анкеты и обоснованной технологии интервью, количественный и качественный анализ полученных материалов позволили получить взвешенные оценки экспертов по разным аспектам социально-экономической, общественно-политической и социокультурной жизни малых городов. Наиболее интересные и значимые оценки разных аспектов жизнедеятельности населения малых городов в российских регионах и государственной политики в их отношении показаны в анализе 4 ключевых из 24 вопросов анкеты, которые и представлены в данной работе. Результаты проведенного исследования пока не претендуют на окончательные выводы, ибо комплексный анализ полученных результатов еще предстоит сделать.

Результаты исследования. Известно, что единство и перспективы российского федеративного государства могут быть обеспечены на основе сбалансированного разделения полномочий и взаимодействия федеральных, региональных, 
местных органов государственной власти по вертикали и горизонтали. Какова же нынешняя ситуация на деле в малых городах? Экспертам был задан вопрос: «Каково влияние власти субъекта РФ, в котором находится Ваш город, на политику управления непосредственно в Вашем малом городе?» Они показали высокую значимость (8-10 баллов по 10-балльной шкале) влияния региональной власти прежде всего на местный бюджет (такую оценку дали 2/3 экспертов) и инвестиции в город (почти половина). Другими словами, преобладает трансфертная политика, лишь покрывающая дефицит местных бюджетов, таким образом поддерживающая малые города (а не инвестиционная, направленная на их развитие). Также почти половина экспертов отметили сверхвысокое влияние региональной власти на формирование органов местного самоуправления, включая главу города, т.е. их прямо подконтрольное положение в «жесткой вертикали», в т.ч. и по немногим оставшимся собственным полномочиям местной власти. Чтобы лучше понять элементы разбалансировки разделения полномочий и взаимодействия разных уровней власти, экспертам был задан уточняющий вопрос: «Каково влияние федеральной власти (законодательной и исполнительной) на различные виды жизнедеятельности Вашего малого города?» Ответы показали ситуацию преобладания автономии местной власти, не подкрепленной ресурсами и поддержкой центральной власти. Более 1/3 экспертов дали сравнительно низкую оценку (36\% ответов) такой поддержке малых городов в бюджетных вопросах. Вместе с тем $28 \%$ респондентов дают высокие баллы такой поддержке. Аналогична и ситуация с поддержкой в инвестициях, в организации территориальной производственной деятельности и социальной сфере в обследуемых малых городах: 1/3 экспертов оценивают эту поддержку как невысокую $(33 \%, 30 \%$ и $30 \%$ соответственно), в то время как 1/4 экспертов оценивают ее как высокую $(27 \%, 26 \%$ и $29 \%$ соответственно). А вот влияние федеральной власти на кадровую политику местных самоуправлений почти половина экспертов оценили как высокое (46\%), что свидетельствует о преобладании авторитарного характера федеральной власти, лишенного, однако, реального и суверенного централизма в государственной политике в виде действующей обратной связи с местными самоуправлениями.

Чтобы лучше понять элементы разбалансировки разделения полномочий и взаимодействия разных уровней власти, экспертам был задан уточняющий вопрос: «Каково влияние федеральной власти (законодательной и исполнительной) на различные виды жизнедеятельности Вашего малого города?» Ответы показали ситуацию преобладания зависимости местной власти, не всегда подкрепленной ресурсами и поддержкой центральной власти. Более 1/3 экспертов дали сравнительно низкую (1-3 балла) оценку федеральной поддержке малых городов в бюджетных вопросах. Вместе с тем более 1/4 ответов содержат высокие баллы $(8-10)$ в оценке такой поддержки. Эксперты этих городов связывают федеральную поддержку с инвестициями в организацию территориальной производственной деятельности и социальную сферу. Такое положение характерно для малых городов, находящихся в агломерациях больших городов (региональных центров). То есть, современная общегосударственная политика, которая фактически направлена на развитие больших городов, таким образом захватывает и малые, но лишь в агломерациях. Влияние федеральной власти на кадровую политику в отношении местного самоуправления в малых городах почти половина экспертов также оценила как очень высокое (вплоть до «ручного управления»), что свидетельствует о преобладании авторитарного характера федеральной власти, действующей не только через региональную власть, но и напрямую, причем без выстроенной системы обратной связи с местным самоуправлением. 
Интересы будущего страны для большинства ее граждан важны сегодня как никогда. Поэтому в экспертной анкете был сформулирован актуальный вопрос: «Как Вы оцениваете необходимость изменений общегосударственной политики в отношении развития малых городов в интересах благополучия, порядка, возможностей для большинства их жителей?» Ответы показали, что такие изменения во всех сферах жизнедеятельности считают необходимыми абсолютное большинство экспертов. Например, в сфере управления (разграничение полномочий и обеспечение реальной самостоятельности местного самоуправления в интересах всех его жителей) за это выступают $81 \%$ экспертов. За обеспечение необходимых финансовых источников для развития всех сфер жизнедеятельности города выступают $87 \%$ экспертов. Большое значение придается развитию производственного сектора экономики (кооперация и развитие средне- и высокотехнологичных предприятий разной формы собственности). Именно этот сектор большинство экспертов считают весьма значимым (5-7 баллов $-44 \%$ ответов) и высоко значимым (8-10 баллов $-49 \%)$ для будущего их города.

Эксперты подчеркивают необходимость комплексного развития малых городов, преодоления диспропорций между экономической и социальной сферами. В этом плане развитие социальных отраслей (образование, здравоохранение, культура, социальная защита и др.) прямо связывается с планированием городского хозяйства (жилье, ЖКХ, инженерные коммуникации, экология), а также с назреванием изменений в правовой и кредитной сферах (оптимизация ограничительно-распорядительных норм для граждан и предпринимателей для развития малого и среднего бизнеса с выделением его особых условий в малых городах).

Вместе с тем наше исследование зафиксировало весьма высокую степень неоднозначности экспертного мнения относительно общей направленности необходимых изменений в политической сфере для судьбы малых городов как социально-территориальных ячеек целостного российского государственного образования. В одном из вопросов анкеты содержались различные варианты, в частности «дальнейшая либерализация экономики» (свобода предпринимательства и развитие индивидуальной инициативы) и «возрождение социалистической модели экономики» (справедливость и равенство для всех). Если первый из приведенных вариантов большинство экспертов оценили минимально (1-3 балла), то по второму оценки сложились в следующем порядке: достаточно значимый (4-7 баллов) - 40\% экспертов, высоко значимый (8-10 баллов) - 19\% экспертов. В то же время заметное число экспертов (17\%) не заняли определенную позицию по данному вопросу. Обычно при обработке экспертных опросов строка в анкете «затрудняюсь ответить» не дает больше 1-3\% ответов. Поэтому почти $1 / 5$ ответов в данной строке свидетельствует о явной неопределенности и разбросе идеологических позиций экспертов, которых можно считать лидерами общественного мнения в малых городах.

Заключительный вопрос анкеты касался актуального положения малых городов, и особенно их будущего. Известно, что в российском общественно-политическом дискурсе в отношении к малым городам сложились две установки. Одна, поддерживаемая президентом, значительным кругом политиков и ученых, заключается в том, что малые города выступают одним их важнейших векторов пространственного развития России, укрепления социально-территориального каркаса российского государства ${ }^{1}$. Поэтому они требуют поддержки и

\footnotetext{
1 Указ Президента РФ от 07.05.2018 г. № 204 «О национальных целях и стратегических задачах развития Российской Федерации на период до 2024 года». Доступ: http//www.kremlin.ru/acts/bank/43027 (проверено 21.10.2019).
} 
развития, особенно в малонаселенных частях страны и отдаленных регионах. Другая установка была выдвинута в свое время Э. Набиуллиной ${ }^{1}$ и поддержана в настоящее время другими влиятельными политиками, которые считают малые города России неперспективными, требующими больших бюджетных затрат и инвестиций, которые могли бы быть направлены в большие города и агломерации с привлечением в них и людей из малых городов, по выражению мэра Москвы, «для улучшения их самочувствия и повышения оптимизма» 2 . Представители такой установки не задумываются, что на огромной территории России концентрация людей в крупных городах чревата распадом единого пространства, ибо формирует при этом демографическую и социально-экономическую деградацию периферийных по отношению к ним территорий страны [Дмитриев, Воронов 2017: 172].

Для выяснения отношения экспертов к данным позициям им был задан вопрос: «Как Вы оцениваете в целом необходимость сохранения и развития всех малых городов в стране, независимо от их потенциала?» Ответы показали следующее. Высокую оценку абсолютного большинства экспертов (93\% ответов) получило мнение о необходимости сохранения малых городов, аргументированное утверждением, что «сохранение и развитие малых городов способствует социально-экономической и национальной безопасности». Также большинство экспертов (87\% ответов) разделяют мнение, что «сохранение и развитие малых городов способствует воспроизводству общероссийских ценностей и норм жизни». Известно, что в настоящих условиях российского «мозаичного» капитализма люди в поисках работы и надежды на лучшую долю концентрируются в мегаполисах, областных центрах, других больших городах, где в известной мере теряют индивидуальность, связь со своей малой родиной и традициями, что ведет к размыванию социальной и культурной идентичности, кризису самоидентификации личности, превращению ее в безликого потребителя. Поэтому в малых городах как первичных социально-территориальных общностях усиливается запрос на возрождение исторически присущих российскому обществу ценностей семьи, справедливости, коллективизма, труда.

Более половины экспертов категорически выступили против возможного укрупнения их городских поселений за счет расселения малых городов или включения их в состав больших городов, даже при социально-экономическом обосновании таких действий.

Выводы. По результатам исследования можно утверждать, что большинство экспертов отвергают подход к будущему малых городов с узко экономических позиций, что подразумевает концентрацию потребителей в крупных агломерациях для роста массы прибыли крупнейших корпораций, коммерческих банков, торговых домов, других субъектов - монополистов рыночной экономики. Функции малых городов в развитии и воспроизводстве общественной жизни российского государства гораздо разнообразнее и глубже, что и утверждается в солидарном экспертном мнении представителей власти, бизнеса и общественности малых городов.

Статья подготовлена в рамках проекта РФФИ 19-011-31320 опн «Малые города в государственной политике пространственного развития России: социальное моделирование региональных стратегий и практик».

\footnotetext{
${ }^{1}$ Башкатова А. 2011. Урбанистические инициативы Эльвиры Набиуллиной. - Независимая газета. 09.12.2011. Доступ: http://www.ng.ru/economics/2011-12-09/1_nabiullina.html (проверено 21.10.2019).

2 Комсомольская правда. 13.09.2019. С. 2; Собянин заявил об абсолютном преимуществе агломераций и мегаполисов. - ИА REGNUM. 12.09.2019. Доступ: https://regnum.ru/news/economy/2717617.html (проверено 21.10.2019).
} 


\title{
Список литературы
}

Дмитриев А.В., Воронов В.В. 2017. Россия в контексте пространственного развития: взгляд с периферии Ближнего Севера. - Мир России. Т. 26. № 4. C. 169-181.

Землянский Д.Ю., Ламанов С.В. 2014. Сценарии развития монопрофильных городов России. - Вестник Московского университета. Сер. География. № 4. C. 69-74.

Малые города, больщие проблемы. Социальная антропология малого города: сборник статей (под ред. М.Е. Кабицкого, О.Ю. Артемовой, М.Ю. Мартыновой). 2014. М.: ИЭА РАН. 358 с.

MARKIN Valeriy Vasil'evich, Dr.Sci. (Soc.), Professor; Principal Researcher at the Sociological Institute - branch of the Federal Center of Theoretical and Applied Sociology, Russian Academy of Sciences (bld. 5, 24/35 Krzhizhanovskogo St, Moscow, Russia, 117218; markin@isras.ru)

VORONOV Victor Vasil'evich, Dr.Sci. (Soc.), Professor; Leading Researcher at the Sociological Institute - branch of the Federal Center of Theoretical and Applied Sociology, Russian Academy of Sciences (bld. 5, 24/35 Krzhizhanovskogo St, Moscow, Russia, 117218; voronov@isras.ru)

\section{SMALL TOWNS OF RUSSIA: EXPERT DIMENSION OF STATE POLICY}

\begin{abstract}
The article based on the results of a field sociological study conducted by the Center for Regional Sociology of the Federal Center of Theoretical and Applied Sociology of the Russian Academy of Sciences in July-August 2019 in 8 federal districts of the Russian Federation, provides expert assessments on the role and factors of life in small towns in Russian regions. Estimates are made in the aspect of the state policy of spatial development of the country. The article shows possibilities and barriers for the implementation of such an effective policy in the interests of the most residents of small towns. The authors show the limitations of a restricted economic approach to the future of small towns, the need to strengthen their role in the production and reproduction of all-Russian values, strengthening the sovereign national security and stability of the country.
\end{abstract}

Keywords: small towns, regions, public policy, expert assessments, development, opportunities and barriers 